\title{
Carbothermic Synthesis of Titanium Diboride: Upgrade
}

\author{
Evgeniy S. Gorlanova, \\ Vladimir Yu. Bazhin ${ }^{* b}$ and Sergey N. Fedorov ${ }^{b}$ \\ a "Expert-Al" LLC \\ 5-7 20-th line, V.O., St. Petersburg, 199106, Russia \\ ${ }^{b}$ St. Petersburg Mining University \\ 21-th line, V.O., St. Petersburg, 199106, Russia
}

Received 15.01.2018, received in revised form 17.01.2018, accepted 26.03.2018

\begin{abstract}
The technology of carbothermic reduction of titanium and boron oxides in the $\mathrm{TiO}_{2}-\mathrm{B}_{2} \mathrm{O}_{3}$-C reaction mixture at temperatures up to $1070{ }^{\circ} \mathrm{C}$ is presented. The temperature and atmospheric regimes of lowtemperature reduction of $\mathrm{TiO}_{2}$ are determined. In the Ti-B-O-C system, successive phase formation of $\mathrm{TiO}_{2} \rightarrow \mathrm{Ti}_{n} \mathrm{O}_{2 n-1} \rightarrow \mathrm{TiBO}_{3} \rightarrow \mathrm{TiC}_{x} \mathrm{O}_{1-x} \rightarrow \mathrm{TiB}_{2}$ at $1030 \div 1050{ }^{\circ} \mathrm{C}$ was realized, which was recorded by X-ray phase analysis of the samples after synthesis. The conditions for the realization of low-temperature synthesis are established, which consist in observing the prescriptions and special regimes for preparing the reaction mixture, the conditions for heating and holding the samples in a controlled atmosphere. For discussion, the mechanism of oxycarboboride phases formation at each of the stages of reduction of activated titanium oxide is presented. The principal possibility of low-temperature synthesis of TiB in the composition of carbon-graphite products by free pitch technology in the conditions of existing kilns is shown.
\end{abstract}

Keywords: sol-gel technology, anatase-rutile transformation, phase formation, low-temperature synthesis, titanium oxycarbide, titanium diboride, dynamic vacuum, controlled atmosphere.

Citation: Gorlanov E.S., Bazhin V.Yu., Fedorov S.N. Carbothermic synthesis of titanium diboride: upgrade, J. Sib. Fed. Univ. Chem., 2018, 11(2), 156-166. DOI: 10.17516/1998-2836-0065.

(C) Siberian Federal University. All rights reserved

* Corresponding author E-mail address: bazhin-alfoil@mail.ru 


\title{
Карботермический синтез диборида титана: апгрейд
}

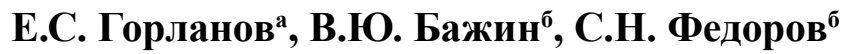 \\ ${ }^{a} О O О$ «Эксперт-Ал» \\ Россия, 199106, Санкт-Петербург, 20-я линия В.О., 5-7 \\ ${ }^{6}$ Санкт-Петербургский горный университет \\ Россия, 199106, Санкт-Петербург, 21-я линия В.О., 2
}

Представлена усовершенствованная технология карботермического восстановления оксидов титана и бора в составе реакционной смеси $\mathrm{TiO}_{2}-\mathrm{B}_{2} \mathrm{O}_{3}$-C при температурах до $1070{ }^{\circ} \mathrm{C}$. Определень температурные и атмосферные режимы низкотемпературного восстановления $\mathrm{TiO}_{2}$. В системе $\mathrm{Ti}-\mathrm{B}-\mathrm{O}-\mathrm{C}$ реализовано последовательное фазообразование $\mathrm{TiO}_{2} \rightarrow \mathrm{Ti}_{n} \mathrm{O}_{2 n-1} \rightarrow \mathrm{TiBO}_{3} \rightarrow \mathrm{TiC}_{x} \mathrm{O}_{1-x} \rightarrow \mathrm{TiB}_{2} \quad$ при $1030 \div 1050 \quad{ }^{\circ} \mathrm{C}, \quad$ которое фиксировалось рентгенофазовым анализом (РФА) образцов после синтеза. Установлены условия реализации низкотемпературного синтеза, которые заключаются в соблюдении рецептов и специиальных режимов подготовки реакционной смеси, условий разогрева и выдержки образцов в регулируемой атмосфере. Для обсуждения представлен механизм образования оксикарбоборидных фаз на каждом из этапов восстановления активированного оксида титана. Показана приниипиальная возможность низкотемпературного синтеза ТіВ в с составе углеграфитовых изделий по безпековой технологии в условиях сущуествующих обжиговых печей.

Ключевые слова: золь-гель технология, анатаз-рутил трансформация, фазообразование, низкотемпературный синтез, оксикарбид титана, диборид титана, динамический вакуум, контролируемая атмосфера.

\section{Introduction}

It is fairly believed that the development of the aerospace or nuclear industry and their military applications does not depend on the cost of innovative materials, and the strategic importance of these areas pays off any material costs. Therefore, it is these industries that have made it possible to improve the methods for synthesizing and compacting expensive powder materials, and to study and expand ideas about the useful properties of carbides, borides, borates and oxycarbides of transition metals. In the system $T i-B-C-O$ is formed a series of compounds of great importance for national economic development. In particular $\mathrm{TiB}_{2}, \mathrm{TiC}$ and $\mathrm{B}_{4} \mathrm{C}$, possessing in a compact form high strength, thermal conductivity, resistance to wear, aggressive media and neutron irradiation, are used as refractories, wear-resistant and heat-resistant coatings and products, armor components, and as absorbing material for regulating rods of nuclear reactors [1]. Such compounds as $\mathrm{TiO}, \mathrm{TiBO}_{3}$ and $\mathrm{TiC}_{x} \mathrm{O}_{1-x}$, being thermally stable semiconductors and having good thermoelectric properties, are used as semiconductor and thermoelectric products in autonomous devices.

However, the complexity of high-temperature $\left(1500 \div 2000{ }^{\circ} \mathrm{C}\right)$ production of powders of these materials causes their high cost and imposes serious restrictions on use in the national economic 
branches of general use. For example, for more than 50 years, the useful properties of $\mathrm{TiO}$ oxide semiconductors for thermoelectric devices [2] or titanium diboride $\mathrm{Ti}_{2}$ have been known as a metallike conductor and refractory [3]. These materials have the potential for revolutionary innovations in metallurgy and in the utilization of "waste" heat from hot sources (surfaces of metallurgical aggregates, waste gases, etc.). However, the high cost (from 100 to $1000 \$ / \mathrm{kg}$ of powder) and the lack of synthesis technologies in industrial volumes hamper their wide application. And this is an objective restriction, because such a high cost in comparison, for example, with carbon products cannot recoup the cost of new materials, even for the entire lifetime of metallurgical units.

In this connection, advanced scientific organizations, world manufacturers of refractories and metals in the last 10-15 years are conducting intensive research studies on the methods of synthesis of refractory materials based on oxides and borides of titanium with the aim of reducing their cost [4-9]. Some progress has been made, but commercial technologies for the production and use of these materials on a large scale have not been reported.

\section{Justification and preparation of carbothermic synthesis}

The present studies of the features and prospects of the refractory compounds synthesis in the $\mathrm{Ti}-\mathrm{B}-\mathrm{O}-\mathrm{C}$ system have been undertaken to remove the economic limitations of the widespread use of titanium borides, oxides and oxycarbides in the metallurgical industry. It is assumed that the use of available and inexpensive starting components for their preparation in low-temperature conditions up to $1070{ }^{\circ} \mathrm{C}$ using simple standard equipment will significantly reduce the cost of these powders to the level of commercial use. Such compounds are oxides of titanium and boron in the hydrated form of metatitanic $\left(\mathrm{H}_{2} \mathrm{TiO}_{3}=\mathrm{TiO}_{2} \cdot \mathrm{H}_{2} \mathrm{O}\right)$ and boric $\left(\mathrm{H}_{3} \mathrm{BO}_{3}=1 / 2 \mathrm{~B}_{2} \mathrm{O}_{3} \cdot 3 / 2 \mathrm{H}_{2} \mathrm{O}\right)$ acids, which make it possible to use solution methods for mixing reagents to increase the reaction surface, in particular sol-gel technology.

But even in this case, the reactions of carbothermic reduction with the participation of three initial reagents at $1030 \div 1070{ }^{\circ} \mathrm{C}$ are endothermic, which requires considerable energy spending for activating the synthesis of oxycarboborides.

$$
\mathrm{TiO}_{2}+\mathrm{B}_{2} \mathrm{O}_{3}+5 \mathrm{C} \leftrightarrow \mathrm{TiB}_{2}+5 \mathrm{CO} \quad \Delta \mathrm{G}_{1300}^{0}=210 \mathrm{~kJ} / \mathrm{mol} .
$$

According to the data of [10-12], reaction (1) at atmospheric pressure becomes thermodynamically possible $\left(\Delta G_{R}<0\right)$ only at $1327^{\circ} \mathrm{C}$ and at $1027^{\circ} \mathrm{C}$, if the pressure in the system is reduced by 100 times. In addition, in the practice of carbothermic reduction, there is a need to increase energy spending by $20-25 \%$ relative to thermodynamically justified.

Overcoming these limitations is assumed using a known feature of titanium oxide - a change in the energy state during the phase transition of anatase to rutile $a-\mathrm{TiO}_{2} \rightarrow r-\mathrm{TiO}_{2}$. During this period, the order of the crystal lattice is rearranged, the mobility of its constituent parts increases and, thus, the reactivity of titanium oxide is stimulated. But anatase-rutile transformation (ART) occurs in the temperature range $600 \div 800{ }^{\circ} \mathrm{C}$ [13], whose energies are insufficient for the phase formation of the target products in the $\mathrm{TiO}_{2}-\mathrm{B}_{2} \mathrm{O}_{3}-\mathrm{C}$ system. In this case, the reduction of stable inactive rutile $\mathrm{r}-\mathrm{TiO}_{2}$ by carbon becomes possible only in the interval $1350 \div 1550{ }^{\circ} \mathrm{C}[11]$.

The most reliable way to stabilize the anatase is to introduce impurity elements into its lattice. In particular, doping of anatase with fluorine under certain conditions can significantly improve its 
stability $[14,15]$ up to the temperature and energy intervals, where possible carbothermic reaction synthesis of titanium oxycarbide in the system $T i-B-O-C$. To implement them in the application to low-temperature conditions, the sol-gel preparation technology for titanium oxide in the initial form of metatitanic acid $\mathrm{H}_{2} \mathrm{TiO}_{3}$ was developed and implemented.

The process of its modification (doping) with fluorine-ion was carried out using hydrolysis according to the scheme:

$$
\mathrm{TiO}_{2} \cdot \mathrm{xH}_{2} \mathrm{O}+\mathrm{NH}_{4} \mathrm{OH}+\mathrm{xHF} \rightarrow \mathrm{TiO}(\mathrm{OH})_{2-\mathrm{x}} \mathrm{F}_{\mathrm{x} \downarrow}+\mathrm{xH}_{2} \mathrm{O}+\mathrm{NH}_{3} \quad \mathrm{x} \leq 1,
$$

which in the presence of hydrofluoric acid (fluoride ion source) and ammonium hydroxide (hydrolysis activator and $\mathrm{pH}$ regulator) proceeds to form a complex precipitate of metatitanic acid. With the heating of the amorphous doped mixture in an air atmosphere at $300 \div 400{ }^{\circ} \mathrm{C}$ during the crystallization of the anatase from the sediment water is removedto obtain a doped anatase.

$$
\mathrm{TiO}(\mathrm{OH})_{2-\mathrm{x}} \mathrm{F}_{\mathrm{x}} \rightarrow \mathrm{a}-\mathrm{TiO}_{2-\mathrm{x}} \mathrm{F}_{\mathrm{x}}+\mathrm{H}_{2} \mathrm{O} \uparrow
$$

To determine the $A R T$ intervals, the fluorine-modified titanium oxide was successively subjected to heating up to $1100{ }^{\circ} \mathrm{C}$ in various atmospheres [16]. Each of the obtained points in the graph reflects the amount of the rutile phase after heating and holding the unmodified $\left(\mathrm{TiO}_{2}\right)$ and doped $\left(\mathrm{TiO}_{2-x} \mathrm{~F}_{x}\right)$ samples at a fixed temperature for 15 minutes.

As follows from the obtained data, heating of amorphous titanium oxide in vacuum and especially in argon stimulates the $A R T$ transition. The increased reactivity of anatase $a-T_{i-x} O_{2-} F_{x}$ at $800 \div 1000{ }^{\circ} \mathrm{C}$ for the longest period is maintained in the presence of oxygen. Therefore, the activation of $a-\mathrm{TiO}_{2-x} F_{x}$ in the $\mathrm{TiO}_{2}-\mathrm{B}_{2} \mathrm{O}_{3}-\mathrm{C}$ reaction mixture assumes its reduction with the formation of a homologous series of $T i_{n} O_{2 n-1}$ oxides simultaneously with the $A R T$ process in the established temperature and atmospheric conditions. Simultaneously is a key definition of the reduction processes of modified titanium oxide. This means that not the final rutil phase $r-\mathrm{TiO}_{2}$ interacts with the carbon, but the intermediate anatase with the crystal lattice in the process of reorganization:

$$
\mathrm{a}-\mathrm{TiO}_{2-\mathrm{x}} \mathrm{F}_{\mathrm{x}}+\mathrm{C} \rightarrow \mathrm{Ti}_{\mathrm{n}} \mathrm{O}_{2 \mathrm{n}-1}+\mathrm{xF} \uparrow \quad(\mathrm{x}=0 \div 1, \mathrm{n}=1 \div 4) .
$$

Thus, it is assumed that in the current temperature range $800 \div 1000{ }^{\circ} \mathrm{C}$, despite the insignificant endothermic barrier of reaction (4), the activated titanium oxide will be successively reduced by carbon to titanium carbide according to scheme

$$
\mathrm{TiO}_{2} \rightarrow \mathrm{Ti}_{4} \mathrm{O}_{7} \rightarrow \mathrm{Ti}_{3} \mathrm{O}_{5} \rightarrow \mathrm{Ti}_{2} \mathrm{O}_{3} \rightarrow \mathrm{TiO} \rightarrow \mathrm{TiC} .
$$

Itisalsoimportant to take into account that the last stage of the $\mathrm{TiO} \rightarrow \mathrm{TiC}$ process is complicated by the formation of a continuous series of solid solutions. As a result, the resulting monoxide and carbide with a lack of oxygen and carbon can be considered as a solid solution of $\mathrm{TiC}$ - $\mathrm{TiO}$ or as titanium carbide, in the lattice of which a part of the carbon atoms is replaced by oxygen atoms $\operatorname{TiC}_{x} O_{1-x}$. This means that this phase is in the process of rebuilding the crystal lattice and is also active for interaction in the reaction mixture $\mathrm{TiO}_{2}-\mathrm{B}_{2} \mathrm{O}_{3}-\mathrm{C}$.

Therefore, freshly formed non-stoichiometric oxycarbides $\operatorname{TiC}_{x} O_{1-x}$ with further heating and aging at $1030 \div 1070{ }^{\circ} \mathrm{C}$ are the best starting phases for the interaction with carbon and boron components with subsequent formation of titanium diboride $\mathrm{TiB}_{2}$.

$$
-159-
$$




$$
\mathrm{TiC}_{\mathrm{x}} \mathrm{O}_{1-\mathrm{x}}+\mathrm{B}_{2} \mathrm{O}_{3}+\mathrm{xC} \rightarrow \mathrm{TiB}_{2}+\mathrm{yCO} .
$$

Thus, it is intended to experimentally confirm and / or clarify the complete cycle of phase formation in the $\mathrm{TiO}_{2}-\mathrm{B}_{2} \mathrm{O}_{3}-\mathrm{C}$ system.

\section{Experiment}

After doping the original amorphous titanium oxide, into its gel-like solution $\operatorname{TiO}(\mathrm{OH})_{2-x} F_{x}$ the remaining components of the reaction mixture boric acid and carbon in the form of sucrose were added successively with constant stirring to a molar ratio of $\mathrm{TiO}_{2}: \mathrm{B}_{2} \mathrm{O}_{3}: \mathrm{C}$ from the stoichiometric ratio of 1: $1: 5$ to 1: 5: 10 . The resulting mixture was dried at room temperature, then at $80-90{ }^{\circ} \mathrm{C}$ in a drying cabinet. The obtained agglomerated $\mathrm{TiO}_{2}-\mathrm{B}_{2} \mathrm{O}_{3}$ - $\mathrm{C}$ composite was heated in a water-cooled sealed cell with the possibility of adjusting the gaseous medium [16]

To maintain titanium oxide in the active state, heating up to $800 \div 1000{ }^{\circ} \mathrm{C}$ was carried out in an air atmosphere. When the temperature reached $800 \div 1000{ }^{\circ} \mathrm{C}$, a dynamic vacuum was installed in the system to remove the evolved gases. After heating to the holding temperature of the system at $1030 \div 1070^{\circ} \mathrm{C}$, a vacuum of about 1-3 $\mathrm{kPa}$ was established for 3-4 hours. In some cases, the completion of the experiment was carried out in an argon atmosphere.

After the end of the exposure at a fixed temperature and the completion of the low-temperature synthesis of the oxycarboboride phases, the reaction cell was cooled to room temperature followed by dismantling. Samples were extracted from the reaction zone, weighed and directed to X-ray phase analysis (radiation of $\mathrm{CuK \alpha}$ ).

\section{The results of the experiment and their discussion}

First of all, it is necessary to verify the possibility of reducing the doped titanium oxide with carbon and determine the order and depth of phase formation when the reaction mixture is heated to $1050{ }^{\circ} \mathrm{C}$. For this purpose, compositions with a molar ratio of $a-\mathrm{TiO}_{2-x} F_{x}: C=1: 13$ were prepared by a solution method. After drying, the black agglomerate was kept under argon atmosphere for 2 hours at $1050{ }^{\circ} \mathrm{C}$.

As follows from the presented results of the analysis of the reaction products $a-\mathrm{TiO}_{2-\mathrm{x}} \mathrm{F}_{x}+\mathrm{C} \rightarrow$ $\rightarrow \mathrm{Ti}_{n} \mathrm{O}_{2 n-1}+x F \uparrow$, the phase formation consistently developed from the anatase phase of $a-\mathrm{TiO}_{2} \rightarrow$ $\rightarrow \mathrm{Ti}_{4} \mathrm{O}_{7} \rightarrow \mathrm{Ti}_{3} \mathrm{O}_{5} \rightarrow \mathrm{Ti}_{x} \mathrm{O}_{1-x}$ to non-stoichiometric titanium oxide. This means that eliminated 2 stages of phase transformations:

1. Rutilization of titanium oxide.

Phase formation develops directly from anatase modification, i.e. in the process of activating the crystal lattice and increasing the reactivity of $\mathrm{TiO}_{2}$.

2. Formation of the $\mathrm{Ti}_{2} \mathrm{O}_{3}$ phase.

Phase $\mathrm{Ti}_{2} \mathrm{O}_{3}$ is not detected, but two main peaks of the $T i_{x} O_{1-x}$ phase are clearly distinguished (Fig. 1), i.e. energetically and kinetically the system is more profitable from $T_{3} \mathrm{O}_{5}$ to proceed to the formation of nonstoichiometric titanium monoxide: $1 / 3 \mathrm{Ti}_{3} \mathrm{O}_{5}+\mathrm{C} \rightarrow \mathrm{Ti}_{x} \mathrm{O}_{l-x}+\mathrm{CO}$.

Thus, the doping of titanium oxide with fluorine allows the system to save energy on phase formation of the homologous series $T i_{n} O_{2 n-1}$ and carry out the process at temperatures below $1070{ }^{\circ} \mathrm{C}$. This is confirmed by the data of the following series of experiments (Fig. 2). At the soak temperature in a discharged atmosphere of up to $1000{ }^{\circ} \mathrm{C}$, only the first two stages of $\mathrm{TiO}_{2} \rightarrow \mathrm{Ti}_{4} \mathrm{O}_{7} \rightarrow \mathrm{Ti}_{3} \mathrm{O}_{5}$ 


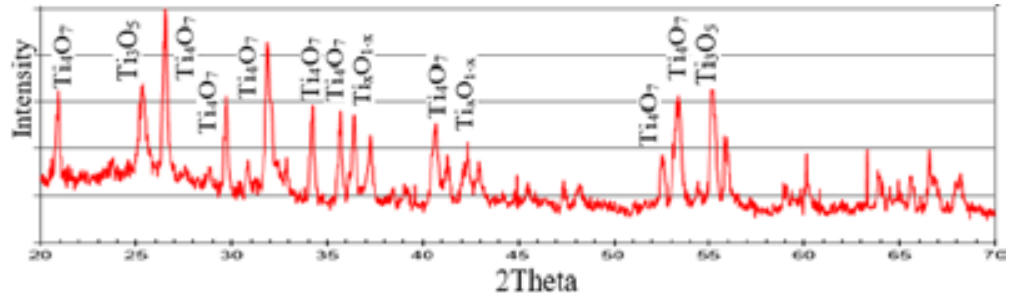

Fig. 1. Results of X-ray phase analysis of $17 i O_{2}$ : $13 \mathrm{C}$ samples after 2 hours at $1050{ }^{\circ} \mathrm{C}$ in a discharged atmosphere

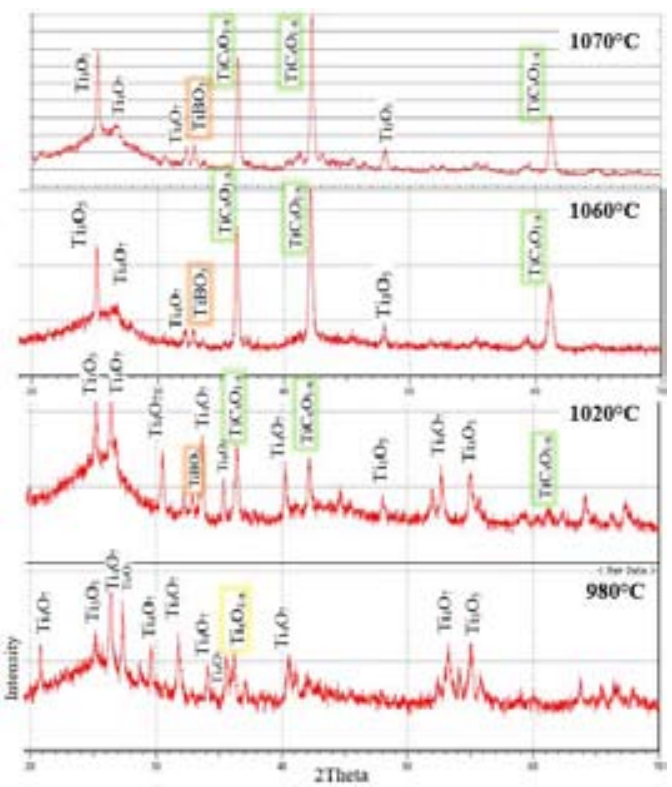

a) exposure 4 hours, vacuum

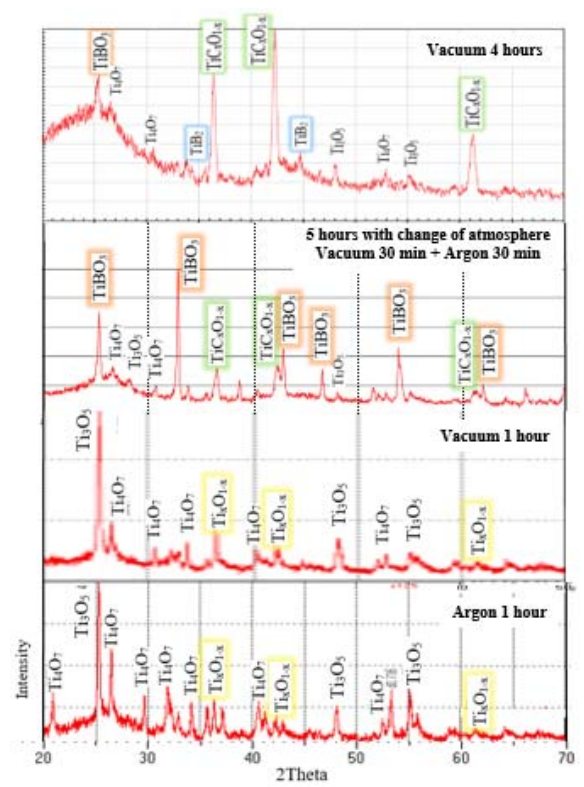

b) exposureat $1050^{\circ} \mathrm{C}$

Fig. 2. Results of X-ray phase analysis of samples $1 \mathrm{TiO}_{2}-2 \mathrm{~B}_{2} \mathrm{O}_{3}-10 \mathrm{C}$

titanium oxide reduction develop with an initial transition to the release of a monoxide at $980{ }^{\circ} \mathrm{C}$ : $\mathrm{Ti}_{3} \mathrm{O}_{5} \rightarrow T i_{x} \mathrm{O}_{1-x}$.

With increasing temperature, the process develops at a high rate. Holding for 1 hour in argon and vacuum atmospheres at $1050{ }^{\circ} \mathrm{C}$ leads to an intensification of the formation of $T i_{x} O_{l-x}$ monoxide. With increasing duration of the exposure in the interval $800 \div 1070{ }^{\circ} \mathrm{C}$ with the participation of $T_{i} O_{1-x}$, two competing processes develop - carbothermic reduction evolves to the non-stoichiometric phase of oxycarbide $\mathrm{TiC}_{x} \mathrm{O}_{1-x}$ and in the contact with $\mathrm{B}_{2} \mathrm{O}_{3}$ the phase formation of yet another intermediate $\mathrm{TiBO}_{3}$ :

$$
\begin{aligned}
& 1 / \mathrm{xTi}_{\mathrm{x}} \mathrm{O}_{1-\mathrm{x}}+(1 / \mathrm{x}+\mathrm{x}) \mathrm{C} \rightarrow \mathrm{TiC}_{\mathrm{x}} \mathrm{O}_{1-\mathrm{x}}+1 / \mathrm{xCO}, \\
& 1 / \mathrm{xTi}_{\mathrm{x}} \mathrm{O}_{1-\mathrm{x}}+1 / 2 \mathrm{~B}_{2} \mathrm{O}_{3} \rightarrow \mathrm{TiBO}_{3} .
\end{aligned}
$$

In general, these two parallel processes can be represented as follows: 


$$
\mathrm{Ti}_{\mathrm{x}} \mathrm{O}_{1-\mathrm{x}}+1 / 2 \mathrm{~B}_{2} \mathrm{O}_{3}+\mathrm{yC} \rightarrow \mathrm{TiBO}_{3}+\mathrm{TiC}_{\mathrm{x}} \mathrm{O}_{1-\mathrm{x}}+\mathrm{zCO} .
$$

A similar dynamics of phase formation was observed by analyzing the products of synthesis at $1030{ }^{\circ} \mathrm{C}$ in a combined atmosphere - successively for 3 hours holding the mixture in vacuo, replacing it with a 2-hour process in argon (Fig. 3).

The limited activity of black carbon and an insufficient amount of boron oxide limit the phase formation with a mixture of simple $\mathrm{Ti}_{4} \mathrm{O}_{7} \rightarrow \mathrm{Ti}_{3} \mathrm{O}_{5}$ and complex oxides of $\mathrm{TiBO}_{3}$ and oxycarbides $\mathrm{TiC}_{x} \mathrm{O}_{1-x}$ in accordance with reaction (8).

When the reaction stoichiometric mixture $\mathrm{TiO}_{2}-\mathrm{B}_{2} \mathrm{O}_{3}-\mathrm{C}$ is formulated with sucrose, the activity of carbon together with the activated state of titanium oxide in the range $800 \div 1030{ }^{\circ} \mathrm{C}$ is sufficient for the appearance of titanium borate as an intermediate phase (Fig. 3b):

$$
\mathrm{TiO}_{2}+1 / 2 \mathrm{~B}_{2} \mathrm{O}_{3}+1 / 2 \mathrm{C} \rightarrow \mathrm{TiBO}_{3}+1 / 2 \mathrm{CO},
$$

which, during aging at $1030{ }^{\circ} \mathrm{C}$, is completely consumed for interaction before the formation of boride and titanium oxycarbide:

$$
2 \mathrm{TiBO}_{3}+(5+2 \mathrm{x}) \mathrm{C} \rightarrow \mathrm{TiB}_{2}+\mathrm{TiC}_{\mathrm{x}} \mathrm{O}_{1-\mathrm{x}}+(5+\mathrm{x}) \mathrm{CO} \quad 0 \leq \mathrm{x} \leq 1 .
$$

Further recovery of titanium oxycarbide

$$
\mathrm{TiC}_{\mathrm{x}} \mathrm{O}_{1-\mathrm{x}}+\mathrm{B}_{2} \mathrm{O}_{3}+2(2-\mathrm{x}) \mathrm{C} \rightarrow \mathrm{TiB}_{2}+(4-\mathrm{x}) \mathrm{CO},
$$

did not develop due to the lack of sufficient boron oxide and carbon. With their shortage, the titanium oxycarbide with an admixture of titanium diboride $\mathrm{TiB}_{2}$ (Fig. $2 b$ and $3 b$ ) was obtained in the experiments under consideration.

As a result, black agglomerates were obtained, a tangible difference which manifested itself in their strength. Samples obtained with a carbonaceous reductant in the form of soot are friable, samples with sucrose were more difficult to grind. For this reason, and in connection with the production of products with a small amount of amorphous phase (absence of "halo" by $2 \Theta$ to $30^{\circ}$ ), which distinguished them from previous synthesis results, the samples of synthesized powders were studied by computer microtomography (SkyScan 1272 microtomograph). It was found that the samples 5a consist of three

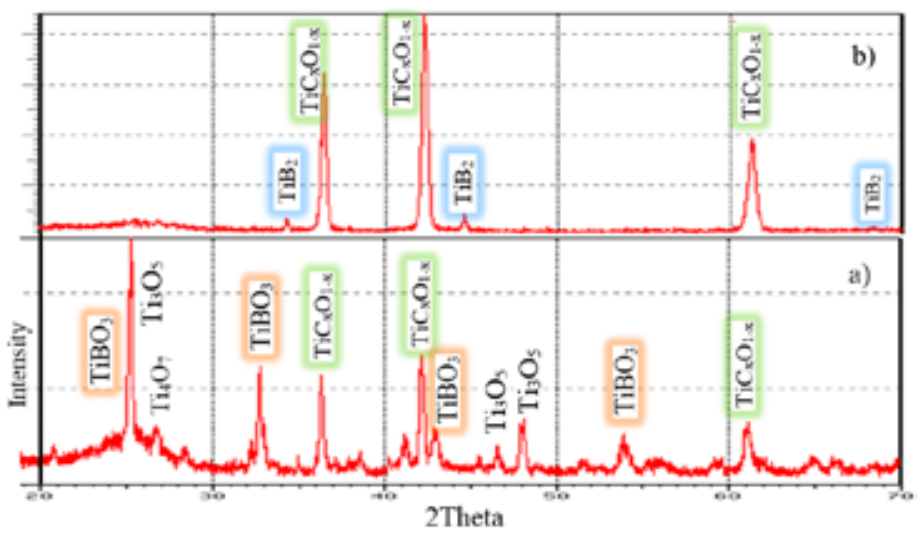

Fig. 3. Results of XRD samples $1 \mathrm{TiO}_{2}-1,3 \mathrm{~B}_{2} \mathrm{O}_{3}-5,4 \mathrm{C}$ after aging at $1030{ }^{\circ} \mathrm{C}$ in a combined atmosphere (3 hours Vacuum +2 hours Argon): a) carbon black, b) sucrose 
phases (Fig. 4), which, according to X-ray diffraction data and X-ray density distribution, obviously correspond to $\mathrm{Ti}_{3} \mathrm{O}_{5}, \mathrm{TiC}_{x} \mathrm{O}_{l-x}$ and $\mathrm{TiBO}_{3}$. Samples $5 \mathrm{~b}$ were identified as $\mathrm{TiB}_{2}$ and $\mathrm{TiC}_{x} \mathrm{O}_{1-x}$ (Fig. 4).

Thus, according to the results of the studies, the following sequence of carbothermic reduction of titanium oxide is detected:

$$
\mathrm{TiO}_{2} \rightarrow \mathrm{Ti}_{\mathrm{n}} \mathrm{O}_{2 \mathrm{n}-1} \rightarrow \mathrm{TiBO}_{3} \rightarrow \mathrm{TiC}_{\mathrm{x}} \mathrm{O}_{1-\mathrm{x}}+\mathrm{TiB}_{2} \rightarrow \mathrm{TiB}_{2}
$$

With the correct composition of the initial reaction mixture and a sufficient number of initial components, the final phase of the synthesis is titanium diboride $\mathrm{TiB}_{2}$.

Taking into account the established features of the phase formation in the $\mathrm{TiO}_{2}-\mathrm{B}_{2} \mathrm{O}_{3}-\mathrm{C}$ system and the dependence of the yield of the final product on the initial composition of the mixture, atmosphere, and the temperature regime of the synthesis, a series of experiments with an increased excess of boron oxide was carried out. In Fig. 5 presents the results of these studies.
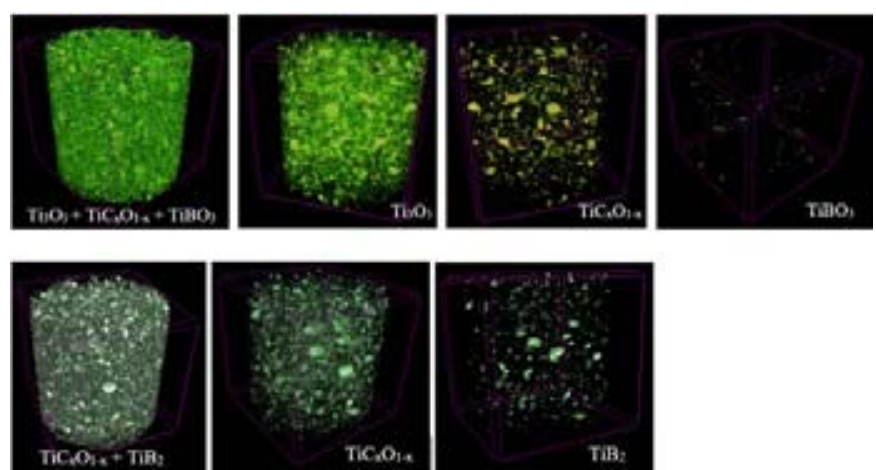

Fig. 4. Microtomography of samples 5a (upper) and 5b (lower)

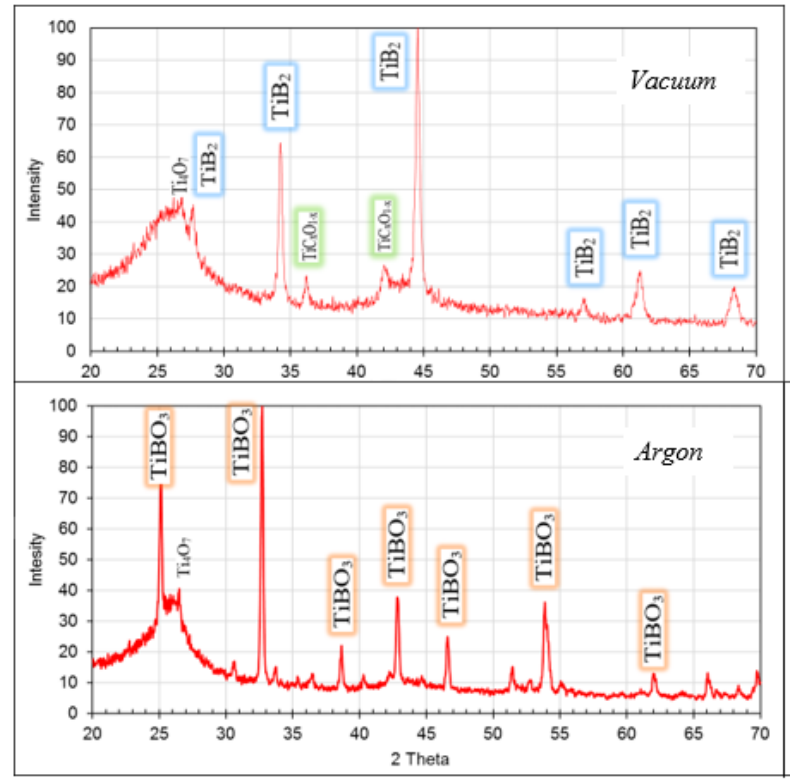

Fig. 5. The results of XRD samples of $1 \mathrm{TiO}_{2}-5,4 \mathrm{~B}_{2} \mathrm{O}_{3}-10 \mathrm{C}$ after holding for 4 hours at $1050{ }^{\circ} \mathrm{C}$ 


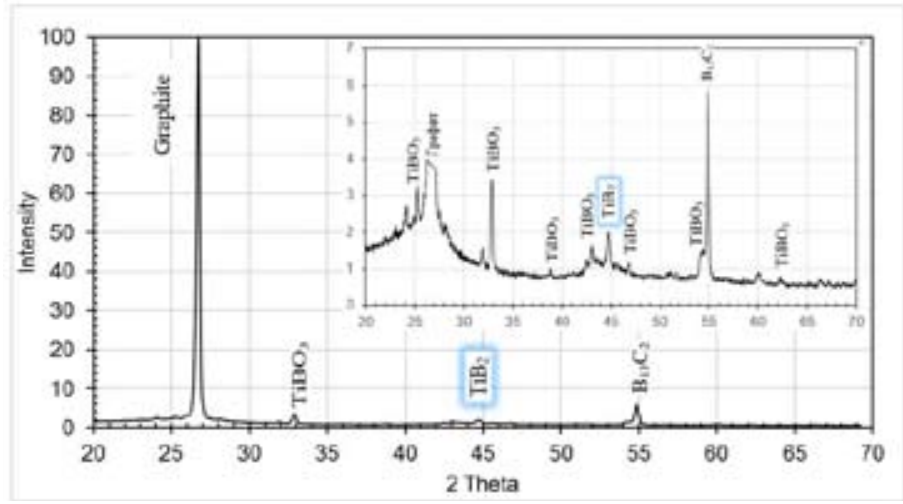

Fig. 6. The results of XRD samples $(\mathrm{G} / \mathrm{A}):\left(1 \mathrm{TiO}_{2}-5,5 \mathrm{~B}_{2} \mathrm{O}_{3}-8 \mathrm{C}\right)=46: 54$ after holding in vacuum at $1050{ }^{\circ} \mathrm{C}$ for 4 hours

Synthesis of $1 \mathrm{TiO}_{2}-5,4 \mathrm{~B}_{2} \mathrm{O}_{3}-10 \mathrm{C}$ mixture in an argon atmosphere at $1050{ }^{\circ} \mathrm{C}$ produced titanium diboride-titanium borate $\mathrm{TiBO}_{3}$ with traces of titanium oxides, which is due to the presence of oxygen in an inert gas:

$$
\mathrm{TiB}_{2}+9 / 4 \mathrm{O}_{2}=\mathrm{TiBO}_{3}+1 / 2 \mathrm{~B}_{2} \mathrm{O}_{3} \uparrow
$$

The experiment in vacuum produced titanium diboride $\mathrm{TiB}_{2}$ with traces of unreduced titanium oxycarbide:

$$
\mathrm{TiC}_{\mathrm{x}} \mathrm{O}_{1-\mathrm{x}}+\mathrm{B}_{2} \mathrm{O}_{3}+2(2-\mathrm{x}) \mathrm{C} \rightarrow \mathrm{TiB}_{2}+(4-\mathrm{x}) \mathrm{CO} .
$$

At the next stage, the preparation and calcination conditions of the graphite / anthracite carbon mixture $(\mathrm{G} / \mathrm{A}=50 / 50)$ with titanium and boron oxides were simulated. A composition $(\mathrm{G} / \mathrm{A})$ : $\left(1 \mathrm{TiO}_{2^{-}}\right.$ $\left.-5,5 \mathrm{~B}_{2} \mathrm{O}_{3}-8 \mathrm{C}\right)=46: 54(\mathrm{wt} \%)$ was prepared by mixing the dry carbon and gelled oxide components, followed by pressing at $200 \mathrm{kgf} / \mathrm{cm}^{2}$, drying the tableted "green" preforms at $60-80^{\circ} \mathrm{C}$ and pre-firing in air at $450{ }^{\circ} \mathrm{C}$ under a layer of petroleum coke.

Pre-prepared samples with a diameter of $26 \mathrm{~mm}$ and a height of 8-10 $\mathrm{mm}$ were placed in a cell under a layer of coke, followed by heating and holding in a moderate vacuum of about $2 \mathrm{kPa}$ at $1050{ }^{\circ} \mathrm{C}$ for 4 hours. The results of XRD products of low-temperature processing are shown in Fig. 6.

On the background of the main graphite component, only the main peaks of $\mathrm{TiB}_{2}, \mathrm{TiBO}_{3}$ and $\mathrm{B}_{13} \mathrm{C}_{2}$ with very low intensity can be identified, which indicates that these compounds are not very high in the final product of low-temperature processing. The method and conditions for the preparation of the initial mixture suggest that the bulk of them are in the intergranular space, that is, the binder of graphite grains of calcined samples. For more information about their presence, the graphite peak is partially removed (the field in the x-ray angle).

The obtained data testify to the principle possibility of synthesis $T i B_{2}$ under conditions close to the conditions for calcination of cathode carbon-graphite blocks. The presence of oxygen in the $\mathrm{CO} / \mathrm{CO}_{2}$ gas mixture leads to oxidation of titanium diboride in the composition of carbon samples to titanium borate $\mathrm{TiBO}_{3}$. Therefore, further studies will be aimed at increasing the concentration of titanium diboride in the composition of carbon products and reducing the effect of the gaseous atmosphere of the calcination cell on the final composition of the composition Carbon-TiB. 


\section{Conclusions}

Doping of amorphous titanium oxide with fluorine allows in the system $\mathrm{TiO}_{2}-\mathrm{C}$ to carry out a full cycle of phase formation in a series of $T_{n} \mathrm{O}_{2 n-1}$ at temperatures below $1000{ }^{\circ} \mathrm{C}$.

The successive phase formation of $\mathrm{TiO}_{2} \rightarrow \mathrm{Ti}_{n} \mathrm{O}_{2 n-1} \rightarrow \mathrm{TiBO}_{3} \rightarrow \mathrm{TiC}_{x} \mathrm{O}_{1-x} \rightarrow \mathrm{TiB}_{2}$ is realized in the $\mathrm{TiO}_{2}-\mathrm{B}_{2} \mathrm{O}_{3}$ - $\mathrm{C}$ system under low-temperature synthesis conditions at $1030 \div 1050{ }^{\circ} \mathrm{C}$.

Depending on the initial composition of the reaction mixture and the final synthesis conditions, one can produce individual products $-\mathrm{TiBO}_{3}, \mathrm{TiC}_{x} \mathrm{O}_{1-x}$ and $\mathrm{TiB}_{2}$.

The principal possibility of low-temperature synthesis of $T i B_{2}$ in the composition of carbon graphite products under conditions of low partial pressure of oxygen in the gas mixture of kilns is shown.

The reaction mixture $\mathrm{TiO}_{2}-\mathrm{B}_{2} \mathrm{O}_{3}$ - $\mathrm{C}$ in the form of a gel can be used as a binder for making carbon or other refractory products (without a bunch of pitch).

\section{References}

1. Свойства, получение и применение тугоплавких соединений. Справ.изд. Под ред. Косолаповой Т.Я. М.: Металлургия, 1986. 928 с. [Properties, production and application of refractory compounds. Ref. ed. Ed. Kosolapova T. Ya. - M.: Metallurgy, 1986. 928 p. (In Russ.)]

2. Иоффе А.Ф. Полупроводниковые термоэлементы. М.; Л.: Изд-во АН СССР, 1960. 188 с. [Ioffe A.F.Semiconductor thermoelements. M.; L.: Publishing House of the USSR Academy of Sciences, 1960. 188 p. (In Russ.)]

3. Patent 3028324 US. Ransley C.E Producing or refining aluminum Pabl. Date 03.04.1962.

4. Axelbaum R.L. Bates S.E., Buhro W. E., Frey C., Kelton K.F., Lawton S. A., Rosen L.J., Sastry S.M.L. Wet chemistry and combustion synthesis of nanoparticles of $\mathrm{TiB}_{2}$. NanoStructured Materials 1993. Vol. 2, P.139-147.

5. Krishnarao R.V., Subrahmanyam J. Studies on the formation of $\mathrm{TiB}_{2}$ through carbothermal reduction of $\mathrm{TiO}_{2}$ and $\mathrm{B}_{2} \mathrm{O}_{3}$. Materials Science and Engineering 2003. A362, P. 145-151.

6. Chen L., Gu Y., Qi Y., Shi L., Yang Z., Ma J. A facile one-step route to nanocrystalline $\mathrm{TiB}_{2}$ powders. Materials Research Bulletin 2004. Vol.39, P.609-613.

7. Ziemnicka-Sylwester M. $\mathrm{TiB}_{2}$-Based Composites for Ultra-High-Temperature Devices, Fabricated by SHS, Combining Strong and Weak Exothermic Reactions. Materials 2013. Vol. 6, P. 19031919 .

8. Патент 2498880 РФ Иванов В.В. и др Способ получения порошка диборида титана для материала смачиваемого катода алюминиевого электролизера. Опубл. 20.11.2013 [Patent 2498880 RU. Ivanov V.V. and etc. Method for obtaining titanium diboride powder for the material of the wettable cathode of an aluminum electrolyzer. Publ. Date 20.11.2013 (In Russ).]

9. Блохина И. А. Карботермический синтез и окисление порошков $\mathrm{TiB}_{2}$. Дисс. ... канд. техн. наук. Красноярск 2015. 122 с. [Blokhina I.A. Carbothermic synthesis and oxidation of $\mathrm{TiB}_{2}$ powders. Diss. to the soisk. uch. Art. Cand. tech. sciences. Krasnoyarsk, 2015. 122 p. (In Russ.)]

10. Bagdavadze J., Tsiskaridze Z., Ukleba K. Thermodynamic analysis of the Ti-O-C system. European Chemical Bulletin 2015. Vol. 4(3), P. 128-129. 
11. Ma Ai-qiong, Ming-xue Jiang, Zhihong W.U. Reactionary mass transfer mechanism of $\mathrm{TiB}_{2}$ synthesized by carbothermal reduction method. The Chinese Journal of Nonferrous Metals 2013. Vol. 23, P. 1605-1610.

12. Hanaor D.A.H., Sorrell Ch. C. Review of the anatase to rutile phase transformation. Journal of Material Science 2011. Vol. 46, P. 855-874.

13. Yu J.C., Yu J.G., Ho W. Effects of F- oping on the photocatalytic activity and microstructures of nanocrystalline $\mathrm{TiO}_{2}$ powders. Chemical Materials 2002. Vol. 14, P. 3808-3816.

14. Седнева Т.А., Локшин Э.П., Белявский А.Т., Калинников В.Т. Зависимость фазовых переходов и фотокаталитической активности наноразмерного диоксида титана от допирования фторид-ионамию. Перспективные материалы 2007. № 6, C. 49-55. [Sedneva T.A., Lokshin E.P., Belyavskii A.T., Kalinnikov V.T. Dependence of phase transitions and photocatalytic activity of nanosized titanium dioxide on doping with fluoride ions. Perspective Materials 2007. Vol. 6, P. 49-55 (In Russ.)]

15. Bazhin V.Yu., Savchenkov S. ., Kosov Yu. . Specificity of the titanium-powder alloying tablets usage in aluminium alloys. Non-ferrous Metals 2016. Vol. 2, P. 52-56.

16. Горланов Е.С. Бажин В.Ю., Федоров С.Н. Низкотемпературное фазообразование в системе Ті-В-С-О. Цветные металль 2017. № 8, C. 76-82. [Gorlanov E.S., Bazhin V.Yu., Fedorov S.N. Low-temperature phase formation in a Ti-B-C-O system. Non-ferrous Metals 2017. Vol. 8, P. 76 82. (In Russ.)] 